\title{
A review of the First Outbreak of the 2019 Novel Coronaviruses (SARS-CoV-2, COVID-19) in Egypt
}

\author{
Mohamed Abumandour, ${ }^{1}$ Naglaa Madkour, ${ }^{1}$ Rasha Tawfik, ${ }^{2}$ Ramzy Abumandour ${ }^{3}$ \\ ${ }^{1}$ Anatomy and Embryology Department, Faculty of Veterinary Medicine, Alexandria University, Egypt \\ ${ }^{2}$ Microbiology department, Faculty of Veterinary Medicine, Alexandria University \\ ${ }^{3}$ Engineering Mechanics at Basic Engineering Sciences department, Faculty of Engineering, Menofia University
}

Disclose and conflicts of interest: none to be declared by all authors

\begin{abstract}
Introduction: this review article was prepared to the represent the outbreak of COVID-19 as a public health emergency in the Egypt in comparison with the most infected countries. Clinical signs of COVID-19 were appeared to be like that recorded in the outbreak of SARS and MERS. Coronaviruses are large enveloped non-segmental virus of a single RNA, which lead to illness case that ranged from the common cold to sever morbidity case. Respiratory signs of COVID-19 were firstly recorded in December of 2019 in Wuhan city, Hubei Province, China. The first outbreak in Egypt occurred on February 14, 2020, for Chinese person at the Cairo International Airport. The outbreak in Men more than in women and rarely occur in children. Mode of transmission of COVID-19 recorded by person-to-person transmission. There is not any specific treatment or vaccine for the COVID-19 infection. The advice for all persons were stay at home, while the infected persons are advised to isolate at hospital. We must follow the words of the Prophet Mohamed recorded about the plague in a number of hadiths 14 centuries ago about the principles of quarantine with the clearest statement.
\end{abstract}

Keywords: COVID-19; Bat; Egypt; Outbreak; WHO

\section{Introduction}

General information about the Coronaviruses

Coronaviruses are large enveloped non-segmental virus of a single RNA-strand, which lead to illness case that ranged from the normal common cold condition to an extreme morbidity case. The coronaviruses have the largest genomic characterization between all RNA viruses so, the coronaviruses have the ability of rapidly adaptation to the new hosts by the genetic recombination and mutation in vitro (CLARIVATE ANALYTICS, 3/6/2020). Moreover, the viral envelope protein is associated with three structural proteins. The medical term of the coronavirus originated from the Latin word "corona", which known as a crown; that assignment emerges from the presence of coronavirus visions saw by electron microscopy, where the infection particles show a crown-like periphery regularly alluded to as "spikes" (LI, 2016) and illustrated in (Fig. 1). The coronavirus is a zoonotic virus as it infected both animals, birds and humans (BISCAYART et al., 2020). The first known coronavirus is the avian infectious bronchitis virus (IB) that isolated in 1937 and lead to damage of the chicken industry until appear vaccine to it. While, the first known human coronavirus was isolated in 1965 in vitro from the nasal cavity (BERRYGAMIELDIEN and FIELDING, 2015, CHAN et al., 2015). There are six types of coronaviruses that lead to human disease; four types lead to mild respiratory signs, but the other two types named the Middle East Respiratory syndrome (MERS) coronavirus and sever acute respiratory syndrome (SARS) that leading to high mortality. Moreover, in December 2019, appear new type of coronavirus named Coronavirus Disease 2019 (COVID-19) that appear in in Wuhan city, Hubei

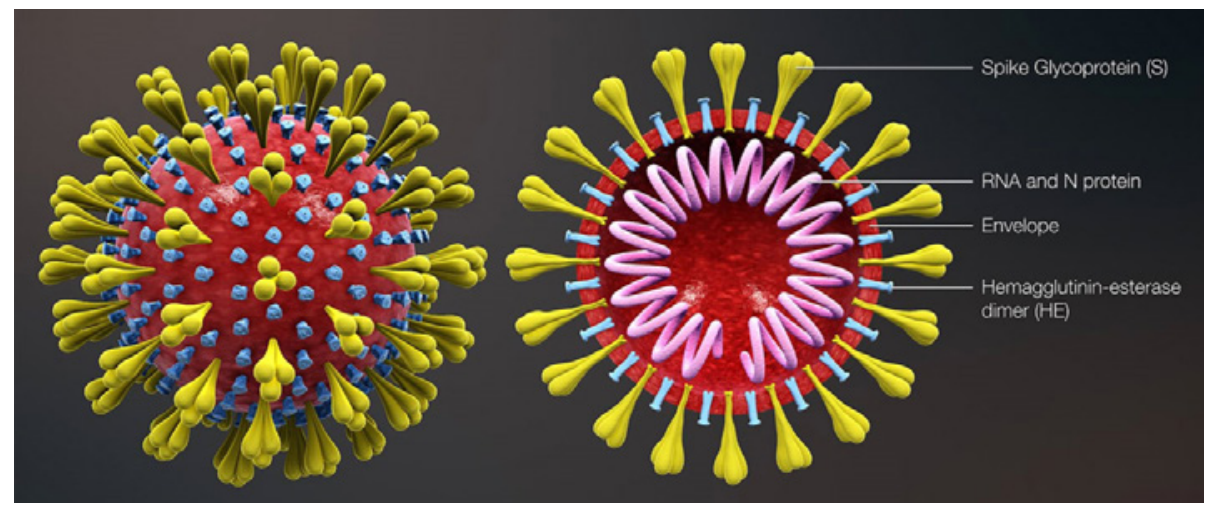

Figure 1: illustrated images describing the crown appearance of the coronavirus.

https://asm.org/Articles/2020/January/2019-Novel-Coronavirus-2019-nCoV-Update-Uncoating 
Province, China and cause severe pneumonia with fever, fatigue, and cough.

The coronaviruses are the most pathogenic factors for all vertebrate including human, in which they infect the respiratory, digestive and central nervous system of human, birds, mouse, bats and other wild animals (WANG et al., 2006, GE et al., 2013). In the previous two decades, there were two other coronaviruses that lead to serious respiratory sickness in people have developed: extreme acute respiratory syndrome coronavirus (SARS-CoV) and the Middle East respiratory syndrome coronavirus (MERS$\mathrm{CoV})$. With the development of SARS-CoV-2, a third coronavirus that can cause serious respiratory ailment has been recognized. In a brief timeframe, this novel coronavirus had caused a bigger number of instances of ailment than were accounted for MERS and SARS combination.

The reports about the emergency condition of SARS-CoV were appeared in February of 2003, with the primary cases saw in Guangdong Province in China. The spread of virus nearly reach to 30 countries around the world, bringing about in excess of 8000 cases and 770 deaths (HUI and ZUMLA, 2019). The outbreak was managed after public health control measures to decrease the direct contact with infected people, and no cases had been seen since 2004. Indications of SARS comprise of fever, headache, chills, and myalgia. The diarrhea was found in certain patients. Pneumonia was almost consistently found in patients determined to have SARS, with mechanical ventilation being required in $10-20 \%$ of cases. Case casualty rate was evaluated at $9-10 \%$.

The common repository for SARS-CoV is thinking to be bats; notwithstanding, some case approved to civet cats or raccoon dogs as conceivable intermediate sources of the illnesses (HUI and ZUMLA, 2019). SARS is transmitted by the close individual to individual contact by the contact of the mucous membranes of the respiratory parts with respiratory droplets that spread from infected individual during the process of coughing or sneezes or speaking. The fecal-oral transmission and transmission (HUI and ZUMLA, 2019). The process of transmission in medicinal services settings was regularly observed during the outbreak in 2003 (RASMUSSEN et al., 2020). The period of incubation was evaluated at a mean of 4.6 days, with a scope of 2-14 days. Transmission seemed to happen frequently during the second seven day stretch of ailment when viral discharge is most elevated; there is no proof that an individual with SARS is infectious before indication beginning.

Coronavirus Disease 2019 (SARS-CoV-2, COVID-19)

Respiratory disease brought about by a novel coronavirus (nearly like that occurred by SARSCoV-2 virus) was firstly recorded in December of 2019 in Wuhan city, Hubei Province, China according to the by the World Health Organization (WHO). The
WHO China Country office was advised of outbreak of pneumonia of unknown cause on December 31, 2019, that infected individual associated with Huanan Seafood Wholesale Market. The (WHO, 2020) recorded the infection of 44 persons in four days at the period between December 31, 2019 and January 3, 2020 and on January 7, 2020, Chinese specialists recognized a novel coronavirus as the reason (WHO, 2020), then on February 5, 2020 the WHO recorded the presence of the 24550 infected cases of Coronavirus Disease 2019 (COVID-19). The first virus spread quickly through Wuhan city and in this way to another Chinese regions and other world countries (WHO, 2020). Early information recommended a relationship between the Huanan Seafood Wholesale Market and COVID-19 with 27 of 41 cases (HUANG et al., 2020) and 26 of 47 (LI et al., 2020) that related epidemiologically to the market, as a result of this the market was closed on January 1, 2020 (RASMUSSEN et al., 2020). In any case, the market's samples recommended that the market's has an important role in early infection transmission (RASMUSSEN et al., 2020). The infection of men more than in women (YANG et al., 2020), also as recorded in the SARS-CoV and MERS-CoV (BADAWI and RYOO, 2016). Moreover, the aged person and patients with diabetes, renal failure, liver failure and cardiac diseases are more suitable than other peoples (ZHANG et al., 2020).

TheSARS-CoV-2 was a described as Beta-coronavirus like SARS-CoV and MERS-CoV. Sequencing information show that the SARS-CoV-2 is closely related firmly to coronaviruses found in bats, with over $85 \%$ nucleotide personality with a bat SARS-like CoV (ZHU et al., 2020, LU et al., 2020). The virus had 79\% nucleotide character to SARS-CoV and about 50\% to MERS-CoV (LU et al., 2020). Bats seem to be the natural reservoirs of both SARS-CoV and MERS-CoV. These viruses' emergency in people has been ascribed to have exchanging: the virus "hopped" from an intermediate host species (as civet cats for SARS-CoV and dromedary camels for MERS-CoV) to people as described in (Fig. 2).

Clinical signs of COVID-19 were appeared to be

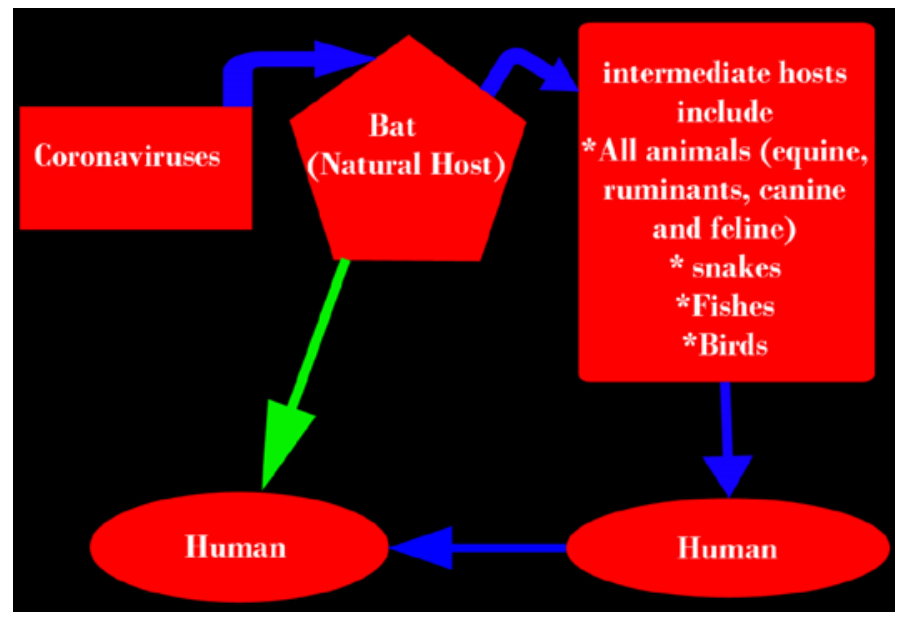

Figure 2. illustrated image describing the mode of transmission of the novel Coronaviruses (SARS-CoV-2, COVID-19) 
like that recorded in the outbreak of SARS and MERS (RASMUSSEN et al., 2020). Investigations of infected patients in hospital with COVID-19 showed that patients normally create serious pneumonia with 23$32 \%$ admitted to the emergency unit $17-29 \%$ of cases advancing to acute respiratory disease syndrome (ARDS) (CHEN et al., 2020, WANG et al., 2020, HUANG et al., 2020). Within the hospitalized patients, $4-15 \%$ were died (CHEN et al., 2020, WANG et al., 2020, HUANG et al., 2020). The estimated total mortality (counting asymptomatic and symptomatic diseases) seem, by all accounts, to be in the scope of $1 \%(95 \%$ certainty interim 0.5-4\%) (DORIGATTI et al., 2020). The hospitalized patients were ranged between 4956 years, with $32-51 \%$ having a hidden disease. Most (54-73\%) patients were men. The detection of the children infected with COVID-19 was rarely happened, with exception of detection of 28 infected children in January 30, 2020 (<1\% of aggregate), but the most symptoms were in mild condition (SHEN and YANG, 2020 ), in addition to there is no any pregnant women were recorded (RASMUSSEN et al., 2020). Normal indications among hospitalized patients were fever (83-100\%), cough (59-82\%), myalgia (11-35\%), headache (7-8\%), and diarrhea (2-10\%) (RASMUSSEN et al., 2020). All patients had variations from the norm on radiographic imaging of the chest (RASMUSSEN et al., 2020).

Person-person transmission of SARS-CoV-2 is believed to be like transmission of influenza and other respiratory pathogens; respiratory droplets are framed when a contaminated individual coughs or sneezes and these respiratory droplets are breathed in by close contacts, by and large inside 6 feet. It is hazy if disease can be transmitted from fomites. Fecal-oral transmission may be conceivable, given that SARS-CoV-2 has been recognized in stool specimens (HOLSHUE et al., 2020) and SARS-CoV may have been transmitted by this way (YU et al., 2004).

\section{Recent outbreak of the COVID-19 virus}

The COVID-19 in the scientific name of the Coronavirus Disease 2019, that it is a developing ailment with a fast increment in cases and deaths since its first recognizable in December 31, 2019 in Wuhan city, China. At present time, the essential epidemiologic hazard factors for COVID-19 incorporate travel from mainland China (Hubei Province) or close contact with infected people within 14 days of appearance of symptoms (WHO, 2020). The virus incubation period ranged from 2-14 day ( $\sim 5$ days). According to that reported by (RASMUSSEN et al., 2020) the average age of the hospitalized patients ranged from 49-56 years, while the children infection is rarely occurred, however there are some cases of children are infected in USA at the last week. Moreover, ratio of the hospitalized men cases reach to 54-73\% (RASMUSSEN et al., 2020). The appeared symptoms of infection include; fever, headache, cough, myalgia, and diarrhea, in addition to the appearance of thoracic abnormalities by radiographic imaging technique, lymphopenia, leukopenia and thrombocytopenia, moreover 17-29\% of hospitalized patients have the acute respiratory distress syndrome (ARDS) (RASMUSSEN et al., 2020) in which this ratio may increase to $50 \%$ in some country as recorded by (WHO, 2020).

From that point forward, the quantity of revealed cases had expanded quickly, with in excess of 51,800 confirmed cases and 1,600 death cases on February 16, 2020. Moreover, to China, cases had spread to different countries including 15 cases for the USA. The first outbreak information from China showed a close to exponential development of revealed cases (ZHAO et al., 2020). The recorded numbers were likely belittling of the true numbers since milder cases were less inclined to be accounted for. On January 30, 2020, the World Health Organization announced the outbreak as a Public Health Emergency of International Concern; in January 31, 2020, the USA proclaimed a public health emergency, and the Centers for Disease Control and Prevention (CDC) gave a government isolate for Americans who went from Wuhan, China, its first federal isolate in over 50 years. On February 11, the new coronavirus ailment (recently alluded to as 2019 novel coronavirus (COVID-19)) got an official name from the World Health Organization (WHO), Coronavirus Disease 19 (COVID-19) (WHO, 2020). The International Committee on Taxonomy of Viruses had proposed SARS-CoV-2 as the name of the infection that causes COVID-19 (GORBALENYA, 2020).

\section{The outbreak of the COVID-19 in Egypt}

Previously, there was any information about the outbreak of the any type of the coronavirus in the Egypt before February 2020. The first recording of the Coronavirus Disease 19 (COVID-19) in the Egypt was described according to the published data by Egypt's health ministry (EGYPT'S HEALTH MINISTRY 14 FEBRUARY 2020).

The first record about the infected person of COVID-19 in Egypt was confirmed on in February 14, 2020 for Chinese person at the Cairo International Airport (EGYPT'S HEALTH MINISTRY 14 FEBRUARY 2020). Then, in the late February to early March, Egypt's health ministry discovered numerous foreign persons with COVID-19 disease; two from USA, two from Tunisia, two from France, one person from Canada and one from Taiwan. On March 8, 2020 Egypt's health ministry confirmed the death of old German citizen (60 years) in Hurghada city (EGYPT'S HEALTH MINISTRY DAILY REPORTS). The second died person, and the infected cases reached to 80 person was reported on March 12, 2020. Then, the virus spread to Egyptian persons that reach to 710 on March 31, 2020 with 54 died cases while the recovered cases 
was reached to 157 person (that out from the isolated hospital) and the person changed from positive to the negative reach to 205 person. The COVID-19 infection affected 24 Egyptian governorates till now (EGYPT'S HEALTH MINISTRY DAILY REPORTS).

An analysis of the epidemiological situation in Egypt compared to the global epidemiological situation, as it showed that the global epidemiological average reached 105 infected person per million citizens, and the death rate reached 5.1 cases per million citizens (EGYPT'S HEALTH MINISTRY DAILY REPORTS). The pointed out that, compared to the epidemiological situation in Egypt, the number of infection per million citizens reached 6 infected cases, while the death rate was 0.4 cases per million citizens, stressing that this average indicates the stability of the epidemiological situation in Egypt so far (EGYPT'S HEALTH MINISTRY DAILY REPORTS).

The low percentage of the infected person in Egypt may related to the usage of the usage of the Bacillus Calmette-Guérin (BCG) vaccine to the children Egyptian (under five years) according to US researchers who summarized the variation of intensity of COVID-19 infection between the different countries. The list of countries that not given the BCG vaccine (such as; USA, France, Italy, Spain) had high intensity of infection, while the countries that vaccinated their children with the BCG vaccine (such as; Egypt, Japan) had low intensity of infection (DIET, 2020). This described by the non-specific immunity produced by the BCG vaccine against numerous viral infections including the COVID-19 as the vaccine increase the secretion of pro-inflammatory cytokines specially the IL-IB that have a role in antiviral immunity by its action as immunodulator that give broad protection against respiratory infections (DEY et al., 2020). We will summarize the table of BCG vaccination in some countries (Table 1).
Actually, right now, the US Food and Drug Administration not reported or advised any specific treatment for the coronavirus infection. Standards of the board of COVID-19 include the process of early isolation, forceful contamination control methodology, oxygen therapy, shirking of liquid over-burden, empiric anti-infection agents (that happen as a secondary bacterial infection), SARS-CoV-2 and co-infection testing, fetal and uterine constriction observing, early mechanical ventilation for dynamic respiratory disappointment, individualized conveyance arranging, and a group based methodology with multi-claim to fame interviews (RASMUSSEN et al., 2020).

The first step is the hospital isolation of infected person. Now, the antiviral therapy with supportive treatment and antibacterial drugs for the secondary infection. The first treatment line is the dealing with fever by antipyretic drugs as paracetamol with oxygen therapy. The treatment according to Chinese health authorities include $a$-interferon, lopinavir (or ritonavir), ribavirin, chloroquine, in addition to immunotherapy for patients with lung diseases and sever diseases. In the USA, the patients were improved with the usage of Remdesivir (MICHELLE L. HOLSHUE, 2020). Moreover, (WEI RUNAN, 2020) recorded that the triple usage of (umifenovir+interferon $a-2 b+l o p i n a v i r$ ritonavir) gave a good result than the usage of the (interferon $a-2 b+l o p i n a v i r$ ritonavir).

Chloroquine had been utilized worldwide for over 70 years, and it was a piece of the World Health Organization (WHO) model rundown of basic drugs for the malaria treatment (AL-BARI, 2015). It is additionally modest and had a built up clinical security profile (COLSONROLAIN and RAOULT, 2020). Notwithstanding, the viability and wellbeing of chloroquine for treatment of SARS-CoV-2 (the new infection causing COVID-19) pneumonia stays indistinct. Moreover, (COLSON et al., 2020) added the first usage of hydroxychloroquine for intracellular bacterial infections.

Treatment of COVID-19 depend on drugs that

\section{Treatment}

Table 1. summarized the relation between the intensity of the infection and the vaccination with BCG vaccine

\begin{tabular}{|c|c|c|c|c|}
\hline Country & Non-vaccinated & Vaccinated & Beginning of vaccination & Rate of infection and mortality \\
\hline Egypt & - & $\checkmark$ & \multirow{3}{*}{ Started vaccination from 1949} & \multirow{3}{*}{ Low infection and mortality } \\
\hline Japan & - & $\checkmark$ & & \\
\hline India & - & $\checkmark$ & & \\
\hline Iran & - & $\checkmark$ & Started vaccination late from 1984 & High infection and mortality \\
\hline Chain & $\checkmark$ & $\checkmark$ & $\begin{array}{l}\text { Vaccination start from } 1966 \text { to } 1976 \\
\text { (then stopped) }\end{array}$ & High infection and mortality \\
\hline USA & $\checkmark$ & \multirow{4}{*}{-} & \multirow{4}{*}{$\begin{array}{l}\text { Now, they start to try to begin BCG } \\
\text { vaccination }\end{array}$} & \multirow{4}{*}{ High infection and mortality } \\
\hline Italy & $\checkmark$ & & & \\
\hline Spain & $\checkmark$ & & & \\
\hline Australia & $\checkmark$ & & & \\
\hline
\end{tabular}


prevent clathrin-mediated endocytosis and therefore prevent viral infection of cells and then the authors described that the target of the drugs are the membranes of the numb-associated kinase (NAKs) family that include AAK1 and GAK, in which their prevention lead to decrease the viral infection at the Vitro (BEKERMAN et al., 2017). The most drug known as a NAK inhibitor is Baricitinib that act as a pivotal regulator of clathrin-mediated endocytosis (STEBBING et al., 2020). Moreover, the combination of three drugs (Baricitinib, Fedratinib and Ruxolitinib) are show a potent anti-inflammatory that act as a JAKSTAT signaling inhibitors (HUANG et al., 2020).

Recently, the research (SHEN et al., 2020) applied on five infected persons with COVID-19 (between 36-65 years including two women) had acute respiratory disease syndrome (ARDS). These patients were recovered after their treatment with antiviral agents then followed by transfusion of the plasma of improvement in clinical status.

\section{Prevention and control}

The vaccine against COVID-19 is not present till now. Since posting of a SARS-CoV-2 virus sequence present online on January 10, 2020, various associations, including the National Institutes of Health, had been attempting to quickly build up a COVID-19 antibody (RASMUSSEN et al., 2020). The process of the synthesis of this vaccine expanded from the study the SARS and MERS vaccines (PAULESMARSTON and FAUCI, 2020). However, it isn't known how rapidly a protected and viable immunization might be promptly accessible.

The advice for all persons is stay at home, while the infected persons are advised to isolate at hospital. The WHO standard advices for the general public is the reduce the exposure to contact with infected persons by stay at home and followed the hand and respiratory hygiene as the following; frequently hands cleaning by alcohol or soap and water, in addition when the person coughing or sneezing must cover the mouth and nose, similar to that advised from 14 centuries ago by the Prophet Mohamed and avoid contact with any persons with fever or cough (KHAN, 2019). The wearing of mask when enter on infected persons.

In Egypt, we must follow the words of the Prophet Mohamed, may God bless him and grant him peace that advise the world in a number of hadiths 14 centuries ago about the principles of quarantine with the clearest statement. The Prophet Mohamed is the first to establish the concept of quarantine 14 centuries ago according to.

1. The first hadith: Narrated Saud; The Prophet said (If you hear of an outbreak of plague in a land, do not enter it; if the plague breaks out in a place while you are in it, do not leave that place) according to Sahih AlBukhari (KHAN, 2019) in (Book 71, Hadith 624).

2. The second hadith Narrated 'Amir bin Sa'd bin Abi Waqqas: That he heard Usama bin Zaid speaking to Sa'd, saying "if the plague appears now and then. So, whoever hears that there is an outbreak of plague in some land, he should not go to that land, and if the plague breaks out in the land where one is already present, one should not run away from that land, escaping from the plague." according to Sahih AlBukhari (KHAN, 2019) in (Book 86, Hadith 104).

3. Narrated 'Abdullah bin 'Amir 'Umar went to Sham and when $\mathrm{h}$ ached Sargh, he got the news that an epidemic (of plague) had broken out in Sham. 'AbdurRahman bin 'Auf told him that Allah's Apostle said, "If you hear that it (plague) has broken out in a land, do not go to it; but if it breaks out in a land where you are present, do not go out escaping from it." (KHAN, 2019) (Book 71, Hadith 626).

\section{References}

Al-Bari, MA. 2015. Chloroquine analogues in drug discovery: new directions of uses, mechanisms of actions and toxic manifestations from malaria to multifariousdiseases. J Antimicrob Chemother 70:1608-1621

Badawi, A, and SG Ryoo. 2016. Prevalence of comorbidities in the Middle East respiratory syndrome coronavirus (MERS-CoV): a systematic review and meta-analysis. International Journal of Infectious Diseases 49:129-133

Bekerman, E, G Neveu, A Shulla, J Brannan, S-Y Pu, S Wang, F Xiao, R Barouch-Bentov, RR Bakken, and R Mateo. 2017. Anticancer kinase inhibitors impair intracellular viral trafficking and exert broadspectrum antiviral effects. The Journal of clinical investigation 127:1338-1352

Berry, M, J Gamieldien, and BC Fielding. 2015. Identification of new respiratory viruses in the new millennium. Viruses 7:996-1019 Biscayart, C, P Angeleri, S Lloveras, T Chaves, P Schlagenhauf, and AJ Rodriguez-Morales. 2020. The next big threat to global health? 2019 novel coronavirus (2019-nCoV): What advice can we give to travellers?-Interim recommendations January 2020, from the Latin-American society for Travel Medicine (SLAMVI). Travel medicine and infectious disease 33:101567

Chan, JF, SK Lau, KK To, VC Cheng, PC Woo, and K-Y Yuen. 2015.
Middle East respiratory syndrome coronavirus: another zoonotic betacoronavirus causing SARS-like disease. Clinical microbiology reviews 28:465-522

Chen, N, M Zhou, X Dong, J Qu, F Gong, Y Han, Y Qiu, J Wang, Y Liu, and $Y$ Wei. 2020. Epidemiological and clinical characteristics of 99 cases of 2019 novel coronavirus pneumonia in Wuhan, China: a descriptive study. The Lancet 395:507-513

Clarivate Analytics. 3/6/2020. Disease Briefing: Coronaviruses.

Colson, P, J-M Rolain, J-C Lagier, P Brouqui, and D Raoult. 2020. Chloroquine and hydroxychloroquine as available weapons to fight COVID-19. International Journal of Antimicrobial Agents

Colson, P, J-M Rolain, and D Raoult. 2020. Chloroquine for the 2019 novel coronavirus. Int J Antimicrob Agents

Dey, RJ, B Dey, AK Singh, M Praharaj, and W Bishai. 2020. Bacillus Calmette-Guérin Overexpressing an Endogenous Stimulator of Interferon Genes Agonist Provides Enhanced Protection Against Pulmonary Tuberculosis. The Journal of Infectious Diseases 221:1048-1056

Diet, H. 2020. Health and Wellness. World Health

Dorigatti, I, L Okell, A Cori, N Imai, M Baguelin, S Bhatia, A Boonyasiri, Z Cucunubá, G Cuomo-Dannenburg, and R Fitzjohn. 2020. Report 4: severity of 2019-novel coronavirus (nCoV). Imperial 
College London, London

Egypt's Health Ministry 14 February 2020. Egypt announces first Coronavirus infection. Archived from the original on 15 February 2020.

Egypt's Health Ministry Daily Reports. outbreak of COVID-19 infection in Egypt. www.mohp.gov.eg.

Ge, X-Y, J-L Li, X-L Yang, AA Chmura, G Zhu, JH Epstein, JK Mazet, B $\mathrm{Hu}, \mathrm{W}$ Zhang, and C Peng. 2013. Isolation and characterization of a bat SARS-like coronavirus that uses the ACE2 receptor. Nature 503:535-538.

Gorbalenya, AE. 2020. Severe acute respiratory syndrome-related coronavirus-The species and its viruses, a statement of the Coronavirus Study Group. BioRxiv.

Holshue, ML, C Debolt, S Lindquist, KH Lofy, J Wiesman, H Bruce, C Spitters, K Ericson, S Wilkerson, and A Tural. 2020. First case of 2019 novel coronavirus in the United States. New England Journal of Medicine.

Huang, C, Y Wang, X Li, L Ren, J Zhao, Y Hu, L Zhang, G Fan, J Xu, and $X$ Gu. 2020. Clinical features of patients infected with 2019 novel coronavirus in Wuhan, China. The Lancet 395:497-506

Hui, DS, and A Zumla. 2019. Severe Acute Respiratory Syndrome: Historical, Epidemiologic, and Clinical Features. Infectious Disease Clinics 33:869-889.

Khan, MM. 2019. The translation of the meaning of Sahih AlBukhari= بر اخبل إي احص: Arabic-English/Muhammad Muslim Khan. Li, F. 2016. Structure, Function, and Evolution of Coronavirus Spike Proteins. . Annual Review of Virology 3:237-261.

Li, Q, X Guan, P Wu, X Wang, L Zhou, Y Tong, R Ren, KS Leung, EH Lau, and JY Wong. 2020. Early transmission dynamics in Wuhan, China, of novel coronavirus-infected pneumonia. New England Journal of Medicine .

Lu, R, X Zhao, J Li, P Niu, B Yang, H Wu, W Wang, H Song, B Huang, and $\mathrm{N}$ Zhu. 2020. Genomic characterisation and epidemiology of 2019 novel coronavirus: implications for virus origins and receptor binding. The Lancet 395:565-574.

Michelle L. Holshue, MC-C. 2020. First Case of 2019 Novel Coronavirus in the United States. New England Journal of Medicine Paules, CI, HD Marston, and AS Fauci. 2020. Coronavirus infectionsmore than just the common cold. Jama 323:707-708.

Rasmussen, SA, JC Smulian, JA Lednicky, TS Wen, and DJ Jamieson. 2020. Coronavirus Disease 2019 (COVID-19) and Pregnancy: What obstetricians need to know. American journal of obstetrics and gynecology.

Shen, C, Z Wang, F Zhao, Y Yang, J Li, J Yuan, F Wang, D Li, M Yang, and L Xing. 2020. Treatment of 5 Critically Ill Patients With COVID-19 With Convalescent Plasma. JAMA.

Shen, K-L, and Y-H Yang. 2020. Diagnosis and treatment of 2019 novel coronavirus infection in children: a pressing issue. Springer Stebbing, J, A Phelan, I Griffin, C Tucker, O Oechsle, D Smith, and P Richardson. 2020. COVID-19: combining antiviral and antiinflammatory treatments. The Lancet Infectious Diseases

Wang, D, B Hu, C Hu, F Zhu, X Liu, J Zhang, B Wang, H Xiang, Z Cheng, and $Y$ Xiong. 2020. Clinical characteristics of 138 hospitalized patients with 2019 novel coronavirus-infected pneumonia in Wuhan, China. Jama.

Wang, L-F, Z Shi, S Zhang, H Field, P Daszak, and BT Eaton. 2006. Review of bats and SARS. Emerging infectious diseases 12:1834 Wei Runan, ZN. 2020. Early antiviral therapy of abidor combined with lopinavir/ritonavir and re-combinant interferon $\alpha-2 b$ in patients with novel coronavirus pneumonia in Zhejiang: A multicenter and prospective study[J/OL]. Chinese Journal of Clinical Infectious Diseases .

Who, WHO. 2020. Coronavirus disease 2019 (' COVID-19): situation. Yang, J, Y Zheng, X Gou, K Pu, Z Chen, Q Guo, R Ji, H Wang, Y Wang, and $Y$ Zhou. 2020. Prevalence of comorbidities in the novel Wuhan coronavirus (COVID-19) infection: a systematic review and metaanalysis. International Journal of Infectious Diseases

Yu, IT, Y Li, TW Wong, W Tam, AT Chan, JH Lee, DY Leung, and T Ho. 2004. Evidence of airborne transmission of the severe acute respiratory syndrome virus. New England Journal of Medicine 350:1731-1739.

Zhang, JJ, X Dong, YY Cao, YD Yuan, YB Yang, YQ Yan, CA Akdis, and YD Gao. 2020. Clinical characteristics of 140 patients infected by SARS-CoV-2 in Wuhan, China. Allergy .

Zhao, S, Q Lin, J Ran, SS Musa, G Yang, W Wang, Y Lou, D Gao, L Yang, and D He. 2020. Preliminary estimation of the basic reproduction number of novel coronavirus (2019-nCoV) in China, from 2019 to 2020: A data-driven analysis in the early phase of the outbreak. International Journal of Infectious Diseases 92:214-217.

Zhu, N, D Zhang, W Wang, X Li, B Yang, J Song, X Zhao, B Huang, $W$ Shi, and R Lu. 2020. A novel coronavirus from patients with pneumonia in China, 2019. New England Journal of Medicine.
Received: July 25, 2021

Accepted: August 30, 2021
Corresponding author

Mohamed Abumandour

E-mail:m.abumandour@yahoo.com or

M.abumandour@alexu.edu.eg. 